\title{
Meer preventie in de zorg: een narratief en uitnodiging vanuit de beleidspraktijk
}

\author{
Luc Hagenaars · Susan Potting
}

Published online: 5 November 2018

(C) Bohn Stafleu van Loghum is een imprint van Springer Media B.V., onderdeel van Springer Nature 2018

De gezondheidszorg krijgt vaak de kritiek dat er te weinig nadruk ligt op preventie. Eind 2014 leidde dat tot een motie van toenmalig Kamerlid Agnes Wolbert, waarin zij de regering vroeg om een overzicht van de mogelijkheden en onmogelijkheden en de voor-en nadelen van een betaaltitel voor selectieve preventie in de Zorgverzekeringswet, inclusief de ervaringen van andere landen [1]. In reactie op deze motie stuurden de toenmalige minister en staatssecretaris van VWS in maart 2016 de brief 'Preventie in het zorgstel: van goede bedoelingen naar het in de praktijk ontwikkelen van resultaten' naar de Tweede Kamer. Deze brief vormde het begin van het beleidsprogramma Preventie in het zorgstelsel [2]. In dit artikel zetten wij namens het Ministerie van Volksgezondheid, Welzijn en Sport (VWS) uiteen welke problemen met dit programma worden aangepakt, welke maatregelen van kracht zijn en welke resultaten het programma tot nu toe heeft opgeleverd. We sluiten af met een blik op de toekomst en een uitnodiging aan 'preventie-innovatoren'.

\section{Knelpuntenanalyse}

VWS heeft naar aanleiding van de motie Wolbert in beeld gebracht wat er speelt als het gaat om selectieve preventie, oftewel preventie voor risicogroepen. Allereerst is onderzocht hoe preventie in de vijf stel-

\footnotetext{
L. Hagenaars ( $\bowtie)$

Directie Macro-Economische vraagstukken en

Arbeidsmarkt, Ministerie van VWS, Den Haag, Nederland ll.hagenaars@minvws.nl

\section{S. Potting}

Directie Publieke Gezondheid, Ministerie van VWS, Den

Haag, Nederland
}

selwetten van VWS is geregeld. ${ }^{1}$ Ten tweede zijn knelpunten in de praktijk opgehaald tijdens vier regionale werkconferenties. Tot slot heeft VWS onderzoeken laten uitvoeren door Zorgmarktadvies en het RIVM [3, $4]$.

Uit deze analyses blijkt dat de verantwoordelijkheden voor preventie in de zorg verdeeld zijn tussen meerdere partijen. Dit is op zichzelf niet zo'n probleem, maar wel als de verantwoordelijkheidstoedeling onduidelijk is. Dit is het geval doordat definities van preventie in de stelselwetten verschillen en een aantal wetten nog niet zo lang van kracht zijn. Mede hierdoor is er sprake van een gefragmenteerd aanbod. Daarbij speelt het knelpunt dat de kosten en de baten in verschillende domeinen neerslaan en er onvoldoende inzicht is in de kosteneffectiviteit. Tegelijkertijd laat de praktijk veel goede initiatieven zien. Deze initiatieven zijn erg divers doordat de lokale omstandigheden verschillen en gemeenten beleidsvrijheid hebben, en de continuïteit vaak afhangt van de inzet van betrokken burgers. Het RIVM concludeert dat de knelpunten die we in Nederland tegenkomen ook spelen in andere landen met andere stelsels.

Fig. 1 geeft weer welke financiers via welke wet verantwoordelijk zijn voor de verschillende verschijningsvormen van preventie in de zorg. De landelijke overheid is samen met gemeenten verantwoordelijk voor collectieve preventie bij de gezonde bevolking. Gemeenten zijn ook verantwoordelijk voor groepen met een verhoogd gezondheidsrisico en individuen met een verhoogd risico. Zorgverzekeraars zijn verantwoordelijk voor individuen met een verhoogd risico (geïndiceerde preventie) of een gezondheidsprobleem (zorggerelateerde preventie). Uitvoerders van de lang-

\footnotetext{
${ }^{1}$ De Wet publieke gezondheid (Wpg), Zorgverzekeringswet (Zvw), Wet langdurige zorg (Wlz), Wet maatschappelijke ondersteuning (Wmo) en de Jeugdwet.
} 
Figuur 1 Schematische weergave van doelgroepen en preventiemaatregelen, wetten en financiers

\section{NEDERLAND}

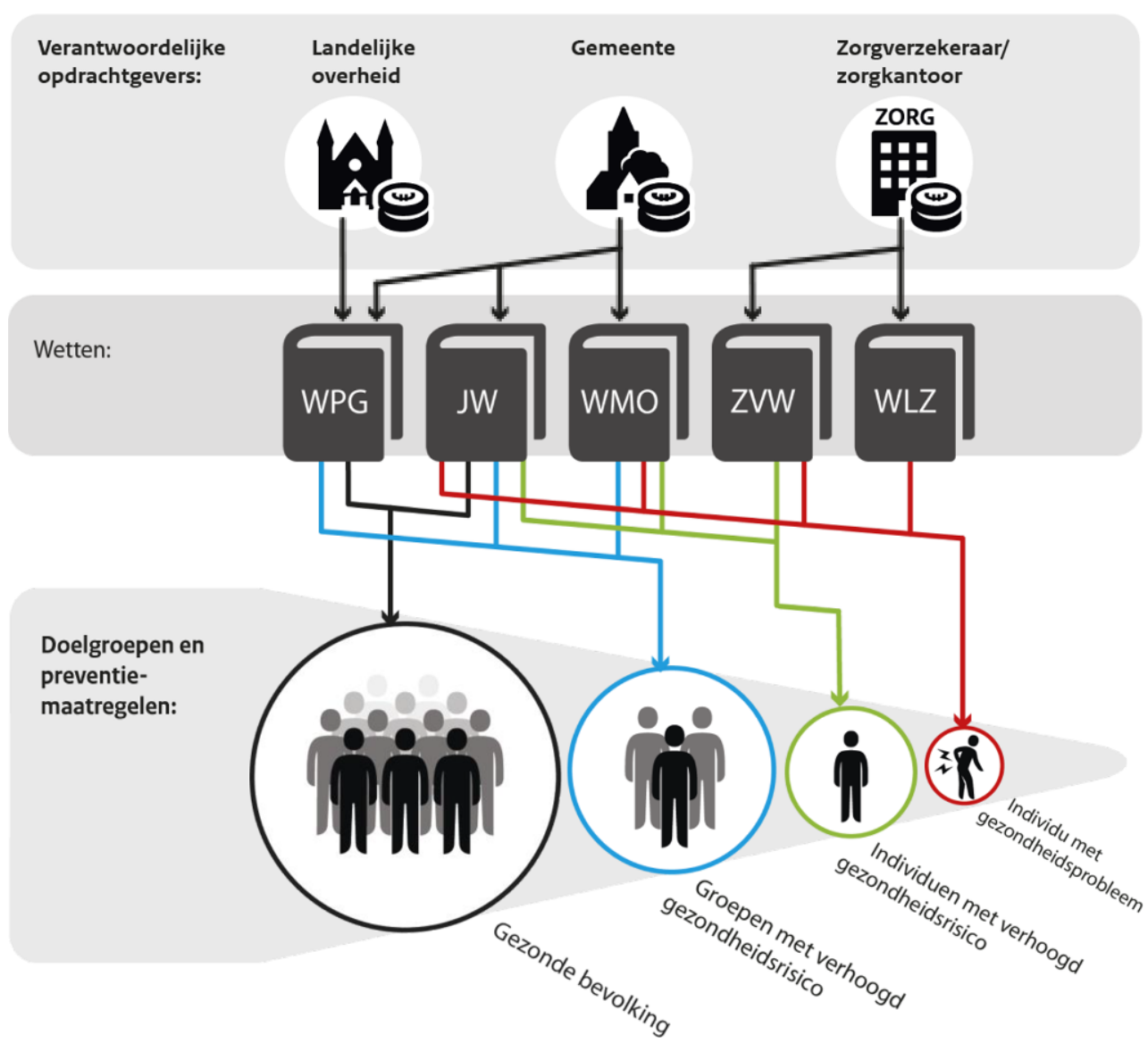

durige zorg zijn ten slotte verantwoordelijk voor preventie bij individuen die permanente langdurige zorg ontvangen.

De figuur laat zien dat veel partijen verantwoordelijkheden hebben, wat samenwerking cruciaal maakt. Dit geldt bij uitstek voor selectieve preventie. Selectieve preventie heeft tot doel de gezondheid van bepaalde risicogroepen te bevorderen door het uitvoeren van specifieke lokale, regionale of landelijke preventieprogramma's. Hierbij is de gemeente aan zet. Zorgverzekeraars financieren geïndiceerde en ziektegerelateerde preventie. In de praktijk is de scheidslijn tussen selectieve en geïndiceerde preventie echter vaag. Zo kan het gaan om dezelfde doelgroep en vergelijkbare activiteiten. Ook kunnen programma's voor groepen gericht zijn op interventies bij individuen en toeleiding naar zorg [5]. Het wiel moet dus telkens opnieuw worden uitgevonden, wat heldere afspraken tussen verzekeraar en gemeente vereist.

\section{Maatregelen}

Deze 'architectuurfase' is echter niet duidelijk belegd bij de verzekeraar of gemeente. Hiervoor is een aantal maatregelen in het leven geroepen:
1. Stimuleren: VWS stimuleert de samenwerking tussen gemeenten en verzekeraars in bestuurlijke overleggen.

2. 'Eerste hulp bij preventie': een digitaal loket met praktische informatie over het opzetten van preventieactiviteiten voor risicogroepen (https://www. loketgezondleven.nl/preventie-het-zorgstelsel-0) en een preventieteam voor verdere vragen en ondersteuning. Dit team bestaat uit ambtenaren vanuit de diverse directies van VWS en andere deskundigen (preventieteam@minvws.nl).

3. Preventiecoalities: VWS stelt subsidie beschikbaar voor een derde van de kosten van procescoördinatie bij het opstarten of uitvoeren van een preventiecoalitie [6]. Verzekeraars kunnen deze subsidie aanvragen wanneer zij met een of meer gemeenten afspraken hebben gemaakt om preventie voor risicogroepen (door) te ontwikkelen.

4. Evaluatie: deze maatregelen gelden vijf jaar. Het RIVM monitort jaarlijks hoeveel samenwerkingsverbanden er tussen zorgverzekeraars en gemeenten zijn. Na afloop vindt een evaluatie plaats waarin de balans wordt opgemaakt $[7,8]$. 
Tabel 1 Overzicht van lopende preventiecoalities (stand september 2018)

\begin{tabular}{|c|c|c|}
\hline Coalitie & Zorgverzekeraar/gemeenten & Thema's \\
\hline Vitaal Twente & Menzis en de 14 Twentse gemeenten & $\begin{array}{l}\text { Preventieactiviteiten voor risicogroepen, met als doel de gezondheid van deze } \\
\text { groep te verbeteren en een vitale regio }\end{array}$ \\
\hline Proeftuin Ruwaard/0ss & CZ, VGZ en Oss & $\begin{array}{l}\text { Effectieve preventieactiviteiten voor risicogroepen, met als doel de gezondheid } \\
\text { van deze groepen te verbeteren } \\
\text { Een gebiedsgerichte, integrale samenwerking en bekostiging van wonen, } \\
\text { welzijn en zorg }\end{array}$ \\
\hline Deventer Promotiecoalitie & ENO en Deventer & $\begin{array}{l}\text { Effectieve preventie voor risicogroepen, met als doel de gezondheid van deze } \\
\text { groepen te verbeteren vanuit het perspectief van positieve gezondheid }\end{array}$ \\
\hline Preventiecoalitie Amstelland & $\begin{array}{l}\text { Zorg en Zekerheid en Amstelveen, Aals- } \\
\text { meer, Ouder-Amstel, Uithoorn }\end{array}$ & $\begin{array}{l}\text { Inzetten van effectieve maatregelen voor valpreventie en het realiseren van } \\
\text { een samenhangende keten voor ouderen met een verhoogd valrisico }\end{array}$ \\
\hline $\begin{array}{l}\text { Preventiecoalitie Samenwerken } \\
\text { aan integrale domeinoverstijgende } \\
\text { zorg }\end{array}$ & $\begin{array}{l}\text { VGZ en Alkmaar, Bergen, Castricum, } \\
\text { Heiloo, Heerhugowaard, Langedijk, } \\
\text { Uitgeest }\end{array}$ & $\begin{array}{l}\text { Verbetering van de gezondheid van kinderen en jeugdigen in de leeftijd } \\
0-18 \text { jaar, van kwetsbare ouderen en mensen met ernstige psychiatrische } \\
\text { aandoeningen }\end{array}$ \\
\hline
\end{tabular}

\section{Preventiecoalities}

Inmiddels zijn er vijf preventiecoalities (tab. 1) en worden op meerdere plaatsen in het land mogelijke coalities verkend. De diversiteit aan thema's, doelgroepen, bereik en aantal partners is groot. In Deventer en Twente wordt de preventiecoalitie gebruikt ter bevordering van een brede integrale aanpak voor risicogroepen, terwijl bijvoorbeeld in Amstelveen sprake is van een focus op valpreventie. Preventiecoalities helpen om 'het balletje te laten rollen'. In een aantal gevallen werd de subsidie verstrekt toen nog maar één gemeente betrokken was, waarna meerdere gemeenten zich later alsnog aansloten. De regeling lijkt dus bij te dragen aan netwerkvorming. Ook treedt in sommige gevallen verbreding op van één focusthema naar meerdere thema's.

Zorgverzekeraars en gemeenten geven aan dat de subsidieregeling helpt omdat de extra gelden tijd vrijmaken voor inspanningen die normaal gesproken 'erbij' worden gedaan. Maar de totstandkoming van een preventiecoalitie vraagt in het voorstadium alsnog om extra inzet, bovenop de reguliere werkzaamheden. Er zijn namelijk verschillen in taal, terwijl ook de besluitvormingsprocessen van verzekeraars en gemeenten anders verlopen. Daarbij moeten goede afspraken worden gemaakt met zorgaanbieders. Deze zoektocht naar gedeelde belangen en win-winsituaties kost tijd. Formalisering van de samenwerking leidt daarnaast niet automatisch tot een continue samenwerking wanneer een breed draagvlak binnen de gemeente ontbreekt om de domeinen preventie, zorg en welzijn met elkaar te verbinden. De intrinsieke motivatie van verzekeraars en gemeenten blijft dus nog steeds een belangrijke voorwaarde.

\section{Andere netwerkinitiatieven}

Niet alle netwerkinitiatieven met een vorm van preventie zijn zover om een preventiecoalitiesubsidie aan te vragen, of achten dit nodig. Die bredere ontwikkelingen worden jaarlijks in beeld gebracht door het RIVM. De tweede monitor liet 71 initiatieven zien waarin gemeenten en verzekeraars preventie, zorg en welzijn met elkaar verbinden [8]. Deze initiatieven verschillen net als de preventiecoalities sterk, maar het terugdringen van eenzaamheid onder ouderen en overgewicht onder kinderen is populair. Bij 28 van deze initiatieven hebben zorgverzekeraars en gemeenten meer of minder formele afspraken gemaakt. In informele samenwerkingsverbanden is er vaak sprake van regelmatig overleg; het wordt formeler als ook een taakverdeling inclusief financiële verplichtingen is afgestemd. Initiatieven richten zich voornamelijk op zorggerelateerde en geïndiceerde preventie, en in mindere mate op universele en selectieve preventie.

Gemeenten en verzekeraars werken ook samen op landelijk niveau, bijvoorbeeld bij de vormgeving van de gemeentepolis voor minima, psychosociale problematiek en de landelijke uitrol van de Gecombineerde Leefstijl Interventie (GLI). De GLI is het noemen waard omdat deze als in te kopen interventie per 1 januari 2019 onderdeel uitmaakt van het basispakket. Verzekeraars hebben dan een zorgplicht om dit leefstijlprogramma in te kopen, zodat verzekerden door een huisarts kunnen worden doorverwezen naar een GLIaanbieder, die deelnemers anzet tot gezonder gedrag, betere voeding en meer bewegen. Om een eenzijdige focus op leefstijl te voorkomen moet de GLIaanbieder nauw contact onderhouden met de huisarts en de sociale kaart goed kennen, om de verzekerde desgewenst te kunnen attenderen op mogelijke ondersteuning door sociaal-maatschappelijke instanties. Samenwerking met gemeenten is ook noodzakelijk omdat begeleiding bij het daadwerkelijke bewegen niet vanuit het basispakket kan worden vergoed. Daarvoor biedt het sociale domein vaak voldoende mogelijkheden. Zo organiseren de meeste gemeenten een gevarieerd beweegaanbod, zoals wandelclubs en walking football. De GLI institutionaliseert dus als het ware samenwerking tussen gemeenten en zorgverzekeraars - althans, op het vlak van dit leefstijlprogramma. Mogelijk draagt deze ontwikkeling ook bij andere thema's bij aan een betere samenwerking tus- 
sen gemeenten en verzekeraars doordat het ze dwingt om elkaars taal beter te leren begrijpen.

\section{Uitnodiging aan preventie-innovatoren}

De bestaande preventiecoalities en bredere ontwikkelingen laten zien dat gemeenten en zorgverzekeraars kunnen, willen en - bijvoorbeeld in het kader van de GLI - moeten samenwerken om hun beider taken effectief uit te voeren. Op veel plaatsen zijn beide partijen daarom met elkaar in gesprek, maken ze concrete afspraken of gaan ze daadwerkelijk samen aan de slag. Vaak zien we een versnelling zodra een preventiecoalitie start. Hoe eerder dit gebeurt, des te sneller dit tot concrete activiteiten leidt. Dit pleit ervoor om niet te veel aan de voorkant te willen regelen, maar de totstandkoming van een preventiecoalitie te gebruiken om afspraken te concretiseren. Voor deze 'architectuurfase' is de subsidieregeling expliciet bedoeld. Het preventieteam van VWS staat daarom open om al vroeg mee te denken in de - gezamenlijke - preventieambities van gemeenten en verzekeraars!

\section{Literatuur}

1. WolbertA. MotieWolbertover een betaaltitelvoor preventie in de zorgverzekeringswet. Vaststelling van de begrotings- staten van het Ministerie van Volksgezondheid, Welzijn en Sport (XVI) voor het jaar 2015. 2015. https://www. parlementairemonitor.nl/9353000/1/j9vvij5epmjley0/ vjplprjzchzg.

2. Kamerstukken II 2015-2016,32793 nr. 213.

3. ZorgmarktAdvies. Financiering van preventie: analyse van knelpunten en inventarisatie van nieuwe oplossingen. Wassenaar:ZorgmarktAdvies; 2015.

4. Heijink R, Struijs J. Preventie in het zorgstelsel: wat kunnen weleren van hetbuitenland? Bilthoven: RIVM;2015.

5. Kroes M, MastenbroekC, Couwenbergh B, etal. Van preventie verzekerd. Diemen: College voor Zorgverzekeringen; 2007.

6. Regeling van de Minister van Volksgezondheid, Welzijn en Sportvan 29 november 2016, kenmerk 1051721-158512-PG, houdende regels voor subsidiëring van de procescoördinatie van preventiecoalities (subsidieregeling preventiecoalities). Staatscourant nr. 66742, 9 december 2016.

7. Lemmens L, Baan C, Drewes H, et al. Samenwerking gemeenten en zorgverzekeraars bij het verbinden van preventie, zorg en welzijn en preventie voor risicogroepen. Bilthoven: RIVM;2017.

8. Vooren $\mathrm{N}$ van, Dorst $\mathrm{H}$ van, Buist Y, et al. Evaluatie Preventie in het Zorgstelsel. Samenwerking gemeenten en zorgverzekeraars ten aanzien van preventie in 2017. Bilthoven: RIVM;2018. 